\title{
Analgesic, anti-inflammatory and hypouricemic effects of GT1 film-coated tablets on experimental animals
}

\author{
Pham Ba Tuyen ${ }^{1, *}, \#$, Truong Thi Huyen ${ }^{1, \#,}$ Pham Xuan Phong ${ }^{2}$, Nguyen Trong Thong ${ }^{3}$, Dinh Thi Thu Hang ${ }^{3}$, \\ Pham Thi Van Anh ${ }^{3}$
}

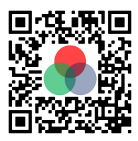

Use your smartphone to scan this QR code and download this article

${ }^{\#}$ Equally contributed to this work

${ }^{1}$ Traditional Medicine Hospital, Ministry of Public Security, Hanoi, Vietnam

${ }^{2}$ Military Institute of Traditional Medicine, Hanoi, Vietnam

${ }^{3}$ Hanoi Medical University, Hanoi, Vietnam

Correspondence

Pham Ba Tuyen, Traditional Medicine Hospital, Ministry of Public Security, Hanoi, Vietnam

Email: phambatuyen.yhct@gmail.com

History

- Received: Mar 09, 2020

- Accepted: Apr 30, 2020

- Published: May 25, 2020

DOI : 10.15419/bmrat.v7i5.603

\section{Check for updates}

\section{Copyright}

(- Biomedpress. This is an openaccess article distributed under the terms of the Creative Commons Attribution 4.0 International license.

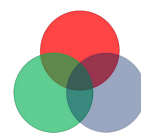

The Open Access Publisher

\begin{abstract}
Aim: To evaluate pain relief, anti-inflammatory and hypouricemic effects of GT1 tablets on experimental animals. Method: GT1 at the doses of $22.32 \mathrm{~g} / \mathrm{kg} /$ day and $66.96 \mathrm{~g} / \mathrm{kg} /$ day were evaluated for its analgesic effect in three models (hot plate, pain threshold, and acetic acid-induced writhing), its chronic anti-inflammatory effect in the granulomatous reaction model, and its hypouricemic effect in potassium oxonate-induced hyperuricemic mice. Acute anti-inflammatory effects of GT1 at the doses of $11.16 \mathrm{~g} / \mathrm{kg} /$ day and $33.48 \mathrm{~g} / \mathrm{kg} /$ day were evaluated in rats with two models: carrageenin-induced paw edema and peritonitis. Results: GT1 prolonged the temperature reaction time on the hot plate $(22.73 \mathrm{~s}$ and $20.37 \mathrm{~s}$ at both doses of $22.32 \mathrm{~g} / \mathrm{kg}$ and $66.96 \mathrm{~g} / \mathrm{kg}$, respectively, compared to $16.96 \mathrm{~s}$ in control group), reduced the number of acid acetic-induced writhing effects, decreased the weight of granulomas, and decreased the level of acid uric in blood and urine $(p<0.05)$. GT1 caused a significant reduction in paw edema after subplantar injection of carrageenan in rats $(p<0.05)$. Moreover, there was a substantial decline of GT1 at the dose of $11.16 \mathrm{~g} / \mathrm{kg} /$ day in terms of the volume and the quantity of protein in the inflammation fluid of the peritonitis model $(p<0.05)$. Conclusion: GT1 at both doses of $11.16 \mathrm{~g} / \mathrm{kg} /$ day and $33.48 \mathrm{~g} / \mathrm{kg} /$ day posed acute anti-inflammatory effects on rats. GT1 at both doses of $22.32 \mathrm{~g} / \mathrm{kg} /$ day and 66.96 $\mathrm{g} / \mathrm{kg} /$ day exerted analgesic, chronic anti-inflammatory and hypouricemic effects on mice.

Key words: GT1, pain relief, anti-inflammatory, hypouricemic
\end{abstract}

\section{INTRODUCTION}

Gout, a consequence of precipitation of monosodium urate crystals in a joint space, is a common chronic condition that mainly causes painful joint inflammation in the first metatarsophalangeal joint ${ }^{1,2}$. Gout is increasingly common given the popularity of poor dietary habit and unhealthy lifestyles, as well as the increase in prevalence of obesity and metabolic syndromes ${ }^{3}$. According to European and American regional statistics, the prevalence of gout was 3-6\% among male populations and 1-2\% among females ${ }^{4}$. Treatments for gout have been well-investigated, and include non-steroidal anti-inflammatory drugs (NSAIDs) and corticosteroids. However, these medications are related to adverse effects ${ }^{5}$. The development of novel therapeutic natural agents is, therefore, important to improve the disease condition ${ }^{6,7}$. In a previous review, traditional herbal medicine was found to have similar efficacy in gout treatment compared to Western medications, with respect to serum uric acid, $\mathrm{C}$ reactive protein, erythrocyte sedimentation rate and overall clinical response ${ }^{8}$. Moreover, traditional medicine was more advantageous, compared to Western medicine, regarding adverse drug reaction control ${ }^{8}$. Therefore, developing traditional herbal medicine regimes for the treatment of goutalong with traditional Western medicine- has great potential and should be considered.

The prevalence of gout in Vietnam is about $0.14 \%$ of the general population and is projected to increase significantly due to the rapid urbanization and lifestyle changes ${ }^{4,9}$. In order to combine modern medicine with traditional medicine, GT1 remedy was developed for gout treatment. GT1 film-coated tablets are prepared from natural materials, including Atractylodes lancea (Thunb.) DC, Phellodendron chinense (Schneid), Achyranthes bidentata (Blume), Lonicera japonica (Thunb.), Anemarrhena asphodeloides (Bunge), Talcum, Milletia reticulata (Benth), Paeonia lactiflora (Pall), Plantago asiatica L, Coix lachryma-jobi L., Dioscorea tokoro (Mahino), and Clematis simensis (Osheck). In the present study, we aimed to validate the anti-inflammatory, antinociceptive activities and hypouricemic effects of GT1 on animal models.

\section{METHODS}




\section{The preparation of GT1 film-coated tablets}

GT1 with standard basis was provided by Traditional Medicine Hospital, Ministry of Public Security, Vietnam. The standard for tablet manufacturing process complied with the current standard basis of Traditional Medicine Hospital, Ministry of Public Security, Vietnam. GT1 was formulated in the form of film-coated tablets, and each tablet had 0.5 mg which was achieved from $0.75 \mathrm{~g}$ Atractylodes lancea (Thunb.) DC, $0.75 \mathrm{~g}$ Phellodendron chinense (Schneid), $0.75 \mathrm{~g}$ Achyranthes bidentata (Blume), 1.0 g Lonicera japonica (Thunb.), $0.75 \mathrm{~g}$ Anemarrhena asphodeloides (Bunge), $0.625 \mathrm{~g}$ Talcum, $1.875 \mathrm{~g}$ Milletia reticulata (Benth), $1.0 \mathrm{~g}$ Paeonia lactiflora (Pall), 0.625 g Plantago asiatica L, 1.875 g Coix lachryma-jobi L., $1.0 \mathrm{~g}$ Dioscorea tokoro (Makino), and $0.625 \mathrm{~g}$ Clematis simensis (Osheck). atients were given orally 4 tablets per day for twice-daily dosing.

\section{Drugs, chemicals and laboratory equip- ment}

Aspirin was collected from Aspirin tablet with a brand-name 100-mg intestinal-soluble tablets (Traphaco Joint Stock Company, Vietnam). Codeine phosphate was supplied by the Central Institute of Drug Quality Control. Methyl prednisolon (Medrol) 4-mg tablet was from Pfizer, Inc (New York, NY). Potassium oxonate, $1 \%$ acetic acid solution, $1 \%$ carrageenan solution, and formaldehyde solution met the laboratory standards and were provided by Hanoi Medical University, Vietnam.

Equipment included: hot plate (model DS37 from Ugo-Basile, 21036 Gemonio VA, Italy), Dynamic Plantar Aesthesiometer 37450 pain response machine (Italy), Ueth-Basile Plethysmometer No7250 (from Ugo-Basile, 21036 Gemonio VA, Italy), biochemical testing machine/ semi-automatic XC -55 chemistry analyzer (China), and Vet abcTM Animal Blood Counter (France). Kits for protein measurement were obtained from Hospitex Diagnostics (Italy), and ABX Minidil LMG blood test solution was from ABX - Diagnostics (78754 Austin, TX).

\section{Experimental animals}

In this study, we used Wistar rats (150-200 $\mathrm{g}$ in weight) and Swiss mice (20-22 g in weight), regardless of sex. Ten rats/mice were housed in cages at the Department of Pharmacology, Hanoi Medical University, Vietnam for at least 1 week prior to investigation. The cages had standard access to rodent diet and water ad libitum. The study protocol was approved by the Institutional Review Board of the Military Institute of Traditional Medicine, Hanoi, Vietnam (Code 05/QD-VYHCTQD, date 04/01/2017).

\section{Methods}

\section{Anti-inflammatory activity}

Carrageenan-induced rat paw edema

The animals were divided into four groups of ten rats per cage: Group 1 (Control group) received distilled water at $0.2 \mathrm{~mL} / 10 \mathrm{~g}$; Group 2 (Positive group) received aspirin at a dose of $200 \mathrm{mg} / \mathrm{kg}$; Group 3 received GT1 at a dose of $11.16 \mathrm{~g} / \mathrm{kg}$; and Group 4 received GT1 at a dose of $33.48 \mathrm{~g} / \mathrm{kg}$.

All the treatments were given continuously for five days. One hour after the first dose, $0.05 \mathrm{~mL}$ of $1 \%$ carrageenan solution in normal saline was injected into the treated paw. Carrageenan-induced swelling and contralateral feet (injected with $0.9 \%$ saline) were measured before carrageenan injection (V0) and at 2 (V2), 4 (V4), 6 (V6) and 24 hours (V24) after the injection. Pedal edema level was evaluated by measuring the left hind paw volume using Plethysmography No 7250 water (Ugo Basile, Italy). Paw thickness was measured using a digital vernier caliper.

\section{Carrageenan-induced peritonitis}

Four groups of ten rats were given the same pretreatments as in the above model. Rats received intraperitoneal injection of $0.05 \mathrm{~g}$ carrageenan and formaldehyde $(1.5 \mathrm{~mL})$ mixed in $100 \mathrm{~mL}$ physiological saline in order to induce inflammation in the peritoneal cavity. All the treatments were given 5 days before the carrageenin and formaldehyde injection. At 24 hours after the injection, the peritoneal fluid was withdrawn and the volume of the fluid, total number of leukocytes, and amount of protein in the peritoneal fluid were counted.

\section{Granuloma method}

The animals were divided into 4 groups of ten mice per cage: Group 1 (Control group) received distilled water at $0.2 \mathrm{~mL} / 10 \mathrm{~g}$; Group 2 (Positive group) received methylprednisolone at a dose of $10 \mathrm{mg} / \mathrm{kg}$; Group 3 received GT1 at a dose of $22.32 \mathrm{~g} / \mathrm{kg}$; and Group 4 received GT1 at a dose of $66.96 \mathrm{~g} / \mathrm{kg}$.

Asbestos fiber weighing $6 \mathrm{mg}$ was sterilized for 1 hour at $120^{\circ} \mathrm{C}$ and embedded in carrageenan (1\%). We aseptically made a subcutaneous tunnel using blunted forceps in the shaved nape skin region of each mice. Each carrageenan-embedded asbestos fiber was then implanted bilaterally in the subcutaneous tunnel. After that, rats were given the treatment with water, drug, or GT1 within 10 days continuously. On the $11^{\text {th }}$ day, the mice were sacrificed. From that point, the pellets encompassed by granuloma tissue were carefully excised and removed from extraneous tissue. 
The damp weight of the asbestos fiber was taken instantly after expulsion; after that, it was dried at $56^{\circ} \mathrm{C}$ for $18 \mathrm{~h}$ and the net dry weight was evaluated.

\section{Analgesic activity}

\section{Hot plate test}

The animals were divided into 4 groups of ten mice per cage: Group 1 (Control group) received distilled water at $0.2 \mathrm{~mL} / 10 \mathrm{~g}$; Group 2 (Positive group) received codeine phosphate at a dose of $20 \mathrm{mg} / \mathrm{kg}$; Group 3 received GT1 at a dose of $22.32 \mathrm{~g} / \mathrm{kg}$; and Group 4 received GT1 at a dose of $66.96 \mathrm{~g} / \mathrm{kg}$.

The hot plate was maintained at $56^{\circ} \mathrm{C}$. The mice of each arm were put in the container (on the hot plate) to watch their reaction to electrical heat-induced pain. At baseline, we measured the normal reaction of the animals to normal temperature before administration of GT1, water or codeine phosphate. At 30 minutes after taking the intervention, we recorded the response time (in seconds) when the rats/mice licked their fore and/or rear paws, as well as jumped. Animals showing a response time more than 30 s or less than $8 \mathrm{~s}$ were disposed of.

\section{Mechanical sensitivity}

Four groups of ten mice each were given same pretreatments as those in the hot plate model. Paw withdrawal latency in reaction to mechanical stimulation was evaluated with an automated testing gadget, comprising of a steel rod that was pushed against the plantar surface of the paw, with expanding drive until the paw was pulled back (Dynamic Plantar Aesthesiometer 37450, Ugo Basile, Italy). Before administration and 1 hour after the final administration, the paw withdrawal latency was assessed, and the drive required to evoke a paw withdrawal reflex was recorded and measured in grams.

\section{Acetic acid-induced writhing test}

Four groups of ten mice were given the same pretreatments as those in the hot plate model; however, the reference analgesic drug was aspirin $(150 \mathrm{mg} / \mathrm{kg})$. On the $5^{\text {th }}$ day, at 1 hour after administration of water, reference drug or GT1, abdominal constriction was induced in mice by intraperitoneal injection of $0.2 \mathrm{~mL}$ acetic acid (1\%). The number of abdominal constrictions was cumulatively counted over a period of 5 minutes within 30 minutes.

\section{Hypouricemic activity}

Animals were divided into five groups ( $\mathrm{n}=10)$ : Group 1 (Control) received distilled water $(0.2 \mathrm{~mL} / 10 \mathrm{~g})$ and was injected with CMC-Na (0.5\%); Group 2 (Model) received distilled water $(0.2 \mathrm{~mL} / 10 \mathrm{~g})$ and was injected intraperitoneally (i.p.) with potassium oxonate; Group 3 was treated with allopurinol $(20 \mathrm{mg} / \mathrm{kg})$ and received i.p. injection of potassium oxonate; and Groups 4 and 5 were treated with GT1 at dose of $22.32 \mathrm{~g} / \mathrm{kg}$ and GT1 $66.96 \mathrm{~g} / \mathrm{kg}$, respectively, and received i.p. injection of potassium oxonate. Once a day for a period of 7 days, water and drug were given by oral gavage. On the 7 th day of the experiment, one hour after treatment, mice were injected with CMC$\mathrm{Na}(0.5 \%)$ and potassium oxonate $(500 \mathrm{mg} / \mathrm{kg})$. The concentrations of acid uric and creatinine in blood and urine were determined.

\section{Data analysis}

Data were shown as mean and standard deviation. Data were analyzed using Microsoft Excel software. The levels of significance between the experimental groups and the control groups were made using Student's t-test; a p-value less than 0.05 was considered as significantly different.

\section{RESULTS}

\section{Anti-inflammatory activity \\ Carrageenan-induced rat paw edema}

Table 1 showed that GT1 at the dose of $11.16 \mathrm{~g} / \mathrm{kg}$ caused a significant reduction in paw edema at six hours after the injection of carrageenan (14.84\% reduction compared to Group 1) and $24 \mathrm{~h}$ after the injection of carrageenan ( $9.87 \%$ reduction compared to Group 1). GT1 at the dose of $33.48 \mathrm{~g} / \mathrm{kg}$ significantly decreased the degree of pedal edema at $6 \mathrm{~h}$ after the injection of carrageenan (15.61\% reduction compared to Group 1).

\section{Carrageenan-induced peritonitis}

Table 2 illustrates that rats treated with GT1 at the dose of $11.46 \mathrm{~g} / \mathrm{kg}$ showed significant reductions in the volume of inflammatory fluid, the total number of leukocytes, and the amount of protein in the peritoneal fluids compared with the control group. However, no significant difference was observed between the GT1 $33.48 \mathrm{~g} / \mathrm{kg}$ dose group and the control group $(\mathrm{p}>0.05)$.

\section{Granuloma method}

Table 3 shows that GT1 at the dose of $66.96 \mathrm{~g} / \mathrm{kg}$ reduced the wet and dry weight of granuloma as compared with the control group ( $\mathrm{p}<0.05)$. There was no considerable change in the weight of the granuloma in the group treated with GT1 $(22.32 \mathrm{~g} / \mathrm{kg}$ dose $)$, when compared with the control group ( $\mathrm{p}>0.05)$. 
Table 1: Effect of GT1 on the degree of pedal edema on carrageenin-induced paw edema in rats

\begin{tabular}{|c|c|c|c|c|}
\hline \multirow[t]{3}{*}{ Time (h) } & \multicolumn{4}{|c|}{$\%$ paw volume } \\
\hline & Group 1 (Control) & Group 2 (Aspirin & Group 3 (GT1 & Group 4 (GT1 \\
\hline & & $200 \mathrm{mg} / \mathrm{kg})$ & $11.16 \mathrm{~g} / \mathrm{kg})$ & $33.48 \mathrm{~g} / \mathrm{kg})$ \\
\hline After $2 h$ & $20.57 \pm 6.09$ & $12.37 \pm 2.80^{* * *}$ & $24.20 \pm 7.83^{+++}$ & $32.62 \pm 8.67^{* *+++}$ \\
\hline After $4 h$ & $54.53 \pm 16.58$ & $30.73 \pm 9.18^{* * *}$ & $43.74 \pm 11.97^{+}$ & $52.11 \pm 16.39^{++}$ \\
\hline After $6 h$ & $52.65 \pm 1214$ & $45.13 \pm 11.75$ & $37.81 \pm 9.20^{* *}$ & $37.04 \pm 10.79^{* *}$ \\
\hline After $24 h$ & $26.36 \pm 5.67$ & $23.55 \pm 7.95$ & $16.49 \pm 3.59^{* * *+}$ & $21.66 \pm 5.05$ \\
\hline
\end{tabular}

${ }^{* *} p<0.01,{ }^{* * *} p<0.001$ compared with group 1

${ }^{+} p<0.05,{ }^{++} p<0.01,{ }^{+++} p<0.001$ compared with group 2

Table 2: Effect of GT1 on the volume of the fluid, total number of leukocytes and the amount of protein in peritoneal fluid

\begin{tabular}{|c|c|c|c|c|}
\hline Group & Group 1 (Control) & $\begin{array}{c}\text { Group } 2 \text { (Aspirin } \\
200 \mathrm{mg} / \mathrm{kg})\end{array}$ & $\begin{array}{r}\text { Group } 3(\mathrm{GT} 1 \\
11.16 \mathrm{~g} / \mathrm{kg})\end{array}$ & $\begin{array}{r}\text { Group } 4 \text { (GT1 } \\
33.48 \mathrm{~g} / \mathrm{kg})\end{array}$ \\
\hline $\begin{array}{l}\text { The volume of fluid } \\
(\mathrm{mL} / 100 \mathrm{~g})\end{array}$ & $1.34 \pm 0.38$ & $\begin{array}{c}0.83 \pm 0.24 \\
* *\end{array}$ & $\begin{array}{c}0.88 \pm 0.27 \\
* *\end{array}$ & $1.94 \pm 0,60$ \\
\hline $\begin{array}{l}\text { Total number of } \\
\text { leukocytes }(G / L)\end{array}$ & $32.48 \pm 7.13$ & $\begin{array}{c}19.21 \pm 6.29 \\
* *\end{array}$ & $\begin{array}{c}18.83 \pm 6.98 \\
* *\end{array}$ & $41.62 \pm 12.73$ \\
\hline $\begin{array}{l}\text { The amount of pro- } \\
\text { tein }(\mathrm{mg} / \mathrm{dL})\end{array}$ & $14.49 \pm 3.06$ & $\begin{array}{c}8.83 \pm 2.83 \\
* * *\end{array}$ & $\begin{array}{c}8.29 \pm 2.70 \\
* * *\end{array}$ & $\begin{array}{c}22.19 \pm 6.36 \\
* *\end{array}$ \\
\hline
\end{tabular}

${ }^{* *} p<0.01,{ }^{* * *} p<0.001$ compared with group 1

Table 3: Effect of GT1 on the wet and dry weight of granuloma

\begin{tabular}{|c|c|c|}
\hline Group & $\begin{array}{l}\text { The wet weight of } \\
\text { granuloma (mg) }\end{array}$ & The dryweight of granuloma (mg) \\
\hline Group 1: Control & $90.76 \pm 18.73$ & $18.53 \pm 6.23$ \\
\hline $\begin{array}{l}\text { Group 2: Methylprednisolon } \\
10 \mathrm{mg} / \mathrm{kg}\end{array}$ & $59.23 \pm 18.33^{* * *}$ & $12.78 \pm 4.08^{*}$ \\
\hline Group 3: GT1 22.32 g/kg/day & $81.50 \pm 22.48^{+}$ & $19.40 \pm 6.28^{++}$ \\
\hline Group 4: GT1 66.96 g/kg/day & $72.70 \pm 19.58^{*}$ & $14.30 \pm 3.11^{*}$ \\
\hline
\end{tabular}

${ }^{*} p<0.05,{ }^{* * *} p<0.001$ compared with group 1

${ }^{+} p<0.05,{ }^{++} p<0.01$ compared with group 2

Table 4: Analgesic effect of GT1 on reaction time

\begin{tabular}{lcc}
\hline Group & \multicolumn{2}{c}{ Reaction time $( \pm$ SD) (s) } \\
& Before & After \\
Group 1: Control & $17.21 \pm 4.78$ & $16.96 \pm 3.46$ \\
Group 2: Methylprednisolon $\mathbf{1 0} \mathbf{~ m g / k g}$ & $18.87 \pm 2.72$ & $21.59 \pm 4.43^{*}$ \\
Group 3: GT1 $22.32 \mathbf{~ g / k g / d a y ~}$ & $18.86 \pm 3.63$ & $22.73 \pm 3.81^{* *}$ \\
Group 4: GT1 $\mathbf{6 6 . 9 6} \mathbf{~ g / k g / d a y ~}$ & $16.70 \pm 2.75$ & $20.37 \pm 3.43^{*}$ \\
\hline
\end{tabular}

${ }^{*} p<0.05,{ }^{* *} p<0.01$ compared with group 1 


\section{Analgesic activity}

\section{Hot plate test}

Table 4 shows that the treatment with GT1 at both doses of $22.32 \mathrm{~g} / \mathrm{kg}$ and $66.96 \mathrm{~g} / \mathrm{kg}$ induced a significant increase in the reaction time on the hot plate, as compared with the control group (22.73 s and $20.37 \mathrm{~s}$, respectively, compared to $16.96 \mathrm{~s}$ for control).

\section{Mechanical sensitivity}

Table 5 demonstrates that after administration of GT1 for 5 days, GT1 at both doses of $22.32 \mathrm{~g} / \mathrm{kg}$ and 66.96 $\mathrm{g} / \mathrm{kg}$ tended to increase the pressure and reaction time as compared with the control group and before the administration. However, the differences were not significant $(\mathrm{p}>0.05)$.

\section{Acid acetic-induced writhing}

Table 6 indicates that there was a considerable reduction in the number of writhings in the group treated with GT1 at the dose of $22.32 \mathrm{~g} / \mathrm{kg}$ at the period of $>20-25$ minutes, when compared with the control group ( $\mathrm{p}<0.05$ ). GT1 at the dose of $66.96 \mathrm{~g} / \mathrm{kg}$ significantly decreased the number of writhings at the periods of $>15-20$ minutes and $>20-25$ minutes, as compared with the control group $(\mathrm{p}<0.05)$.

\section{Hypouricemic activity}

Table 7 and Table 8 show that GT1 at both doses of $22.32 \mathrm{~g} / \mathrm{kg}$ and $66.96 \mathrm{~g} / \mathrm{kg}$ decreased the concentration of acid uric in blood and urine, as compared with the control group. GT1 at both doses of $22.32 \mathrm{~g} / \mathrm{kg}$ and $66.96 \mathrm{~g} / \mathrm{kg}$, however, did not significantly change the concentration of creatinine in blood and urine, when compared with the control group ( $\mathrm{p}>0.05)$.

\section{DISCUSSION}

Acute inflammation has typical symptoms such as pain, swelling, heat or redness. Therefore, measuring swelling degree is a good indicator for experimentally-induced acute inflammation. In our study, oral administration of GT1 was capable of decreasing paw volume of rats, volume of peritoneal fluid, total number of leukocytes, and amount of protein, as well as inhibiting granuloma formation, when compared with the control group. Therefore, GT1 induces a positive effect in animal models of acute and chronic inflammation.

Pain is known to be often associated with inflammation ${ }^{10}$. In this study, the antinociceptive effect of GT1 was evaluated using in vivo models including the hot plate model, mechanical sensitivity test, and acid acetic-induced nociception test. GT1 at both doses of $22.32 \mathrm{~g} / \mathrm{kg}$ and $66.96 \mathrm{~g} / \mathrm{kg}$ significantly increased the reaction time on the hot-plate, tended to increase the pressure and reaction time on the dynamic plantar aesthesiometer, and reduced the number of writhings as compared with the control group. These results indicate that GT1 expresses central and peripheral analgesic activities.

Hyperuricemia could be a major hazardous factor for gout and chronic nephritis in the clinical setting ${ }^{11}$. In this study, GT1 at both doses of $22.32 \mathrm{~g} / \mathrm{kg}$ and $66.96 \mathrm{~g} / \mathrm{kg}$ decreased the concentration of acid uric in blood and urine, when compared with the control group. GT1 at both doses did not significantly change the concentration of creatinine in blood and urine, as compared with the control group. These results indicated that GT1 potentiated the analgesic, anti-inflammatory and hypouricemic effects. This was due to the effect of the main components in GT1. According to the research of Ryu (2010), SKLJI, an extract from Lonicera japonica, is a viable candidate for new anti-inflammatory and analgesic phytomedicine ${ }^{12}$. WIN-34B, an extract from Lonicera japonica and Anemarrhena asphodeloides (Bunge), exhibited anti-inflammatory and analgesic activities in vitro and in vivo ${ }^{13,14}$. He DY and Dai SM (2011) reported on the anti-inflammatory and analgesic activities of Paeonia lactiflora (Pall) in vivo and in vitro ${ }^{15}$. According to Yang Q (2019), polysaccharides purified from Lonicera japonica expressed anti-hyperuricemic and anti-gout effects through significantly reducing serum uric acid and suppressing xanthine oxidase activity $^{16}$. Results from the study of Yang Fei (2016) showed that Dioscorea tokoro (Makino) at a dose of $880 \mathrm{mg} / \mathrm{kg}$ decreased levels of serum uric acid, increased levels of urine uric acid, and inhibited xanthine oxidase activity in both serum and liver ${ }^{11}$.

\section{CONCLUSIONS}

GT1 at the doses of $11.16 \mathrm{~g} / \mathrm{kg} /$ day and 33.48 $\mathrm{g} / \mathrm{kg} /$ day mediated an acute anti-inflammatory effect on rats. GT1 at both doses of $22.32 \mathrm{~g} / \mathrm{kg} /$ day and $66.96 \mathrm{~g} / \mathrm{kg} /$ day exerted analgesic, chronic antiinflammatory and hypouricemic effects on mice.

\section{ABBREVIATIONS}

NSAIDs: Non-steroidal anti-inflammatory drugs

\section{ACKNOWLEDGMENTS}

We would acknowledge the support from staff of Traditional Medicine Hospital, Ministry of Public Security, Hanoi, Vietnam. 
Table 5: Analgesic effect of GT1 on pain state model using mechanical stimuli

\begin{tabular}{lcccc}
\hline Group & \multicolumn{2}{c}{ Pressure (g) } & \multicolumn{2}{c}{ Reaction time (s) } \\
& \multicolumn{1}{c}{ Before } & After & Before & After \\
Group 1: Control & $9.20 \pm 1.52$ & $10.29 \pm 1.42$ & $5.31 \pm 0.92$ & $5.97 \pm 0.87$ \\
$\begin{array}{l}\text { Group 2: Methyl- } \\
\text { prednisolon }\end{array}$ & $9.47 \pm 1.70$ & $11.81 \pm 1.72^{*}$ & $5.48 \pm 1.03$ & $6.90 \pm 1.08^{*}$ \\
$\begin{array}{l}\text { 10mg/kg } \\
\text { Group 3: GT1 22.32 }\end{array}$ & $9.93 \pm 2.52$ & $10.56 \pm 3.30$ & $5.75 \pm 1.52$ & \\
g/kg/day & & & $6.17 \pm 1.96$ \\
$\begin{array}{l}\text { Group 4: GT1 66.96 } \\
\text { g/kg/day }\end{array}$ & $10.24 \pm 0.98$ & $10.77 \pm 2.90$ & $5.94 \pm 0.60$ & \\
\hline
\end{tabular}

${ }^{*} p<0.05$ compared with group 1

Table 6: Analgesic effect of GT1 on acid acetic induced writhing model

\begin{tabular}{|c|c|c|c|c|c|c|}
\hline \multirow[t]{2}{*}{ Group } & \multicolumn{6}{|c|}{ The number of writhings } \\
\hline & $\begin{array}{l}0-5 \\
\text { minute }\end{array}$ & $\begin{array}{l}>5-10 \\
\text { minute }\end{array}$ & $\begin{array}{l}>10-15 \\
\text { minute }\end{array}$ & $\begin{array}{l}>15-20 \\
\text { minute }\end{array}$ & $\begin{array}{l}>20-25 \\
\text { minute }\end{array}$ & $>25-30$ minute \\
\hline Control & $10.30 \pm 3.40$ & $20.70 \pm 6.45$ & $18.10 \pm 5.97$ & $14.70 \pm 3.95$ & $12.50 \pm 3.37$ & $8.90 \pm 2.18$ \\
\hline $\begin{array}{l}\text { Aspirin } \\
150 \mathrm{mg} / \mathrm{kg}\end{array}$ & $2.30 \pm 1.06^{* * *}$ & $\begin{array}{l}10.80 \pm \\
2.90^{* * *}\end{array}$ & $\begin{array}{l}8.50 \pm \\
2.27^{* * *}\end{array}$ & $\begin{array}{l}7.60 \pm \\
1.84^{* * *}\end{array}$ & $\begin{array}{l}4.70 \pm \\
1.77^{* * *}\end{array}$ & $4.20 \pm 1.40^{* * *}$ \\
\hline $\begin{array}{l}\text { GT1 } \\
22.32 \mathrm{~g} / \mathrm{kg}\end{array}$ & $\begin{array}{c}11.80 \pm \\
3.52^{+++}\end{array}$ & $\begin{array}{c}21.10 \pm \\
6.74^{+++}\end{array}$ & $\begin{array}{c}18.00 \pm \\
3.16^{+++}\end{array}$ & $\begin{array}{c}14.70 \pm \\
4.60^{+++}\end{array}$ & $\begin{array}{c}9.50 \pm \\
2.07^{*+++}\end{array}$ & $8.10 \pm 2.92^{+++}$ \\
\hline $\begin{array}{l}\text { GT1 } \\
66.96 \mathrm{~g} / \mathrm{kg}\end{array}$ & $\begin{array}{c}11.50 \pm \\
3.89^{+++}\end{array}$ & $\begin{array}{c}19.00 \pm \\
5.68^{+++}\end{array}$ & $\begin{array}{c}15.60 \pm \\
4.93^{+++}\end{array}$ & $\begin{array}{c}10.30 \pm \\
3.13^{*+}\end{array}$ & $\begin{array}{c}9.30 \pm \\
2.67^{*+++}\end{array}$ & $7.10 \pm 1.97^{+++}$ \\
\hline
\end{tabular}

${ }^{*} p<0.05,{ }^{* * *} p<0.001$ compared with group 1

${ }^{+} p<0.05,{ }^{+++} p<0.001$ compared with group 2 (aspirin)

Table 7: Effect of GT1 on the concentration of acid uric in blood and urine

\begin{tabular}{lcc}
\hline Group & $\begin{array}{c}\text { The concentration of serum acid uric } \\
(\mu \mathrm{mol} / \mathrm{mL})\end{array}$ & $\begin{array}{c}\text { The concentration of urine acid uric } \\
(\mu \mathrm{mol} / \mathrm{mL})\end{array}$ \\
Group 1 (control) & $16.00 \pm 4.71$ & $18.70 \pm 5.91$ \\
Group 2 (model) & $21.70 \pm 5.42^{*}$ & $28.00 \pm 8.45^{*}$ \\
Group 3 (allopurinol 20 & $14.20 \pm 3.97^{\Delta \Delta}$ & $19.30 \pm 6.02^{\Delta}$ \\
mg/kg) & & \\
Group 4 (GT1 22.32 g/kg) & $16.20 \pm 3.97^{\Delta}$ & $14.50 \pm 2.59^{\Delta \Delta \Delta}$ \\
Group 5 (GT1 66.96 g/kg) & $17.80 \pm 2.15^{\Delta}$ & $17.80 \pm 5.75^{\Delta \Delta}$ \\
\hline
\end{tabular}

${ }^{*} p<0.05$ compared with group 1

${ }^{\Delta} p<0.05,{ }^{\Delta \Delta} p<0.01,{ }^{\Delta \Delta \Delta} p<0.001$ compared with group 2 (model) 
Table 8: Effect of GT1 on the concentration of creatinine in blood and urine

\begin{tabular}{lcc}
\hline Group & $\begin{array}{c}\text { Concentration of creatinine } \\
\text { in blood }(\mathbf{m g} / \mathbf{d L})\end{array}$ & $\begin{array}{c}\text { Concentration of creatinine in urine } \\
(\mathbf{m g} / \mathbf{d L})\end{array}$ \\
Group 1 (control) & $0.48 \pm 0.12$ & $5.03 \pm 1.25$ \\
Group 2 (model) & $0.48 \pm 0.15$ & $5.28 \pm 1.00$ \\
Group 3 (allopurinol $20 \mathbf{~ m g / k g )}$ & $0.48 \pm 0.12$ & $5.99 \pm 1.17$ \\
Group 4 (GT1 22.32 $\mathbf{~ / ~} / \mathbf{k g})$ & $0.53 \pm 0.14$ & $4.99 \pm 0.75$ \\
Group $5(\mathbf{G T 1} \mathbf{6 6 . 9 6} \mathbf{g} / \mathbf{k g})$ & $0.55 \pm 0.17$ & $5.38 \pm 0.81$ \\
\hline
\end{tabular}

\section{AUTHOR'S CONTRIBUTIONS}

Conceptualization: Pham Ba Tuyen, Truong Thi Huyen. Formal analysis: Pham Ba Tuyen, Truong Thi Huyen, Pham Xuan Phong. Investigation: Truong Thi Huyen, Pham Xuan Phong, Dinh Thi Thu Hang. Methodology: Pham Ba Tuyen, Truong Thi Huyen, Pham Xuan Phong, Nguyen Trong Thong, Dinh Thi Thu Hang, Pham Thi Van Anh. Project administration: Pham Xuan Phong, Nguyen Trong Thong. Writing-original draft: Pham Ba Tuyen, Truong Thi Huyen, Pham Xuan Phong, Nguyen Trong Thong, Dinh Thi Thu Hang, Pham Thi Van Anh. Writing. Review \& editing: Pham Ba Tuyen, Truong Thi Huyen, Pham Xuan Phong, Nguyen Trong Thong, Dinh Thi Thu Hang, Pham Thi Van Anh. All authors gave final approval of the version to be published; and agree to be accountable for all aspects of the work.

\section{FUNDING}

This study received funding from the Traditional Medicine Hospital, Ministry of Public Security.

\section{AVAILABILITY OF DATA AND MATERIALS}

Data and materials used and/or analysed during the current study are available from the corresponding author on reasionable request.

\section{ETHICS APPROVAL AND CONSENT TO PARTICIPATE}

Not applicable.

\section{CONSENT FOR PUBLICATION}

Not applicable.

\section{COMPETING INTERESTS}

The authors declare that they have no competing interests.

\section{REFERENCES}

1. Hainer BL, Matheson E, Wilkes RT. Diagnosis, treatment, and prevention of gout. American family physician.
2014;90(12):831-836.

2. Goodman LS. Goodman and Gilman's the pharmacological basis of therapeutics. McGraw-Hill New York. 1996;.

3. Ragab G, Elshahaly M, Bardin T. Gout: An old disease in new perspective - A review. Journal of advanced research. 2017;8(5):495-511. PMID: 28748116. Available from: https: //doi.org/10.1016/j.jare.2017.04.008.

4. Kuo CF, Grainge MJ, Zhang W, Doherty M. Global epidemiology of gout: prevalence, incidence and risk factors. Nature reviews Rheumatology. 2015;11(11):649-662. PMID: 26150127. Available from: https://doi.org/10.1038/nrrheum.2015.91.

5. Soskind R, Abazia DT, Bridgeman MB. Updates on the treatment of gout, including a review of updated treatment guidelines and use of small molecule therapies for difficult-to-treat gout and gout flares. Expert opinion on pharmacotherapy. 2017;18(11):1115-1125. PMID: 28658988. Available from: https://doi.org/10.1080/14656566.2017.1349099.

6. Kabir I, Imtiyaz A. A review on in vivo and in vitro experimental models to investigate the anti-inflammatory activity of herbal extracts. Asian Journal of Pharmaceutical and Clinical Research. 2018;11:29. Available from: https://doi.org/10. 22159/ajpcr.2018.v11i11.26873.

7. Khanna D, Fitzgerald JD, Khanna PP, Bae S, Singh MK, Neogi $T$, et al. American College of Rheumatology guidelines for management of gout. Part 1: systematic nonpharmacologic and pharmacologic therapeutic approaches to hyperuricemia. Arthritis Care Res (Hoboken). 2012;64(10):14311446. PMID: 23024028. Available from: https://doi.org/10. 1002/acr.21772.

8. Zhou L, Liu L, Liu X, Chen P, Liu L, Zhang Y, et al. Systematic review and meta-analysis of the clinical efficacy and adverse effects of Chinese herbal decoction for the treatment of gout. PLoS ONE. 2014;9(1):e85008. PMID: 24465466. Available from: https://doi.org/10.1371/journal.pone.0085008.

9. Minh-Hoa TT, J JD, SL SLC, Hung NV, Nhi CT, An TN. Prevalence of the rheumatic diseases in urban Vietnam: a WHO-ILAR COPCORD study. The Journal of rheumatology. 2003;30(10):22522256.

10. Hassan Fl, Zezi AU, Yaro AH, Danmalam UH. Analgesic, antiinflammatory and antipyretic activities of the methanol leaf extract of Dalbergia saxatilis Hook.F in rats and mice. J Ethnopharmacol. 2015;166:74-78. PMID: 25771356. Available from: https://doi.org/10.1016/j.jep.2015.03.007.

11. Fei Y, Ye D, Fan XF, Dong F. Effect of Dioscorea tokoro Makino extract on hyperuricemia in mice. Tropical Journal of Pharmaceutical Research. 2016;15:1883-1887. Available from: https: //doi.org/10.4314/tjpr.v15i9.10.

12. Ryu KH, Rhee HI, Kim JH, Yoo H, Lee BY, Um KA, et al. Anti-inflammatory and analgesic activities of SKLJl, a highly purified and injectable herbal extract of Lonicera japonica. Biosci Biotechnol Biochem. 2010;74(10):2022-2028. PMID: 20944425. Available from: https://doi.org/10.1271/bbb. 100279. 
13. Kim KS, Choi HM, Yang HI, Yoo MC. WIN-34B May Have Analgesic and Anti-Inflammatory Effects by Reducing the Production of Pro-Inflammatory Mediators in Cells via Inhibition of I $\kappa$ B Signaling Pathways. Biomol Ther (Seoul). 2012;20(1):5056. PMID: 24116274 . Available from: https://doi.org/10.4062/ biomolther.2012.20.1.050.

14. Kang $\mathrm{M}$, Jung I, Hur J, Kim SH, Lee JH, Kang JY, et al. The analgesic and anti-inflammatory effect of WIN-34B, a new herbal formula for osteoarthritis composed of Lonicera japonica Thunb and Anemarrhena asphodeloides BUNGE in vivo. J Ethnopharmacol. 2010;131(2):485-496. PMID: 20643199.
Available from: https://doi.org/10.1016/j.jep.2010.07.025.

15. He DY, Dai SM. Anti-inflammatory and immunomodulatory effects of paeonia lactiflora pall, a traditional chinese herbal medicine. Frontiers in Pharmacology. 2011;2:10. Available from: https://doi.org/10.3389/fphar.2011.00010.

16. Yang $Q$, Wang $Q$, Deng W, Sun C, Wei Q, Adu-Frimpong M, et al. Anti-hyperuricemic and anti-gouty arthritis activities of polysaccharide purified from Lonicera japonica in model rats. Int J Biol Macromol. 2019;123:801-809. PMID: 30445085. Available from: https://doi.org/10.1016/j.ijbiomac.2018.11.077. 